United States Department of Energy

Savannah River Site

\title{
Statement of Basis/Proposed Plan for the Motor Shops Seepage Basin (716-A) (U)
}

WSRC-RP-97-839

Revision 0

December 1997

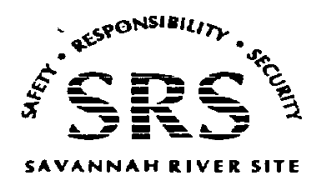


This document was prepared in conjunction with work accomplished under Contract No.

DE-AC09-96SR18500 with the U.S. Department of Energy.

\section{DISCLAIMER}

This report was prepared as an account of work sponsored by an agency of the United States Government. Neither the United States Government nor any agency thereof, nor any of their employees, makes any warranty, express or implied, or assumes any legal liability or responsibility for the accuracy, completeness, or usefulness of any information, apparatus, product or process disclosed, or represents that its use would not infringe privately owned rights. Reference herein to any specific commercial product, process or service by trade name, trademark, manufacturer, or otherwise does not necessarily constitute or imply its endorsement, recommendation, or favoring by the United States Government or any agency

thereof. The views and opinions of authors expressed herein do not necessarily state or reflect those of the United States Government or any agency thereof.

This report has been reproduced directly from the best available copy.

Available for sale to the public, in paper, from: U.S. Department of Commerce, National Technical Information Service, 5285 Port Royal Road, Springfield, VA 22161, phone: (800)

553-6847, fax: (703) 605-6900, email: orders@ntis.fedworld.gov online ordering: http://www.ntis.gov/ordering.htm

Available electronically at http://www.doe.gov/bridge

Available for a processing fee to U.S. Department of Energy and its contractors, in paper, from: U.S. Department of Energy, Office of Scientific and Technical Information, P.O. Box 62, Oak Ridge, TN 37831-0062, phone: (865 ) 576-8401, fax: (865) 576-5728, email: reports@ adonis.osti.gov 


\title{
DISCLAIMER
}

This report was prepared by Westinghouse Savannah River Company (WSRC) for the United States Department of Energy under Contract No. DE-AC09-96-SR18500 and is an account of work performed under that contract. Reference herein to any specific commercial product, process, or services by trademark, name, manufacturer or otherwise does not necessarily constitute or imply endorsement, recommendation, or favoring of same by WSRC or by the United States Government or any agency thereof.

\author{
Printed in the United States of America \\ Prepared for \\ U. S. Department of Energy \\ and \\ Westinghouse Savannah River Company \\ Aiken, South Carolina
}




\section{CERTIFICATION}

Statement of Basis/Proposed Plan for the

716-A Motor Shops Seepage Basin (U)

WSRC-RP-97-839, Rev.0

December, 1997

"I certify under the penalty of law that this document and all attachments were prepared under my direction or supervision in accordance with a system designed to assure that qualified personnel properly gather and evaluate the information submitted. Based on my inquiry of the person or persons who manage the system, the information submitted is, to the best of my knowledge and belief, true, accurate, and complete. I am aware that there are significant penalties for submitting false information, including the possibility of fines and imprisonment for knowing violations."

Date: 4 DEC $97 \quad$ Signature:

Date: Nec. 4,1997

Signature:
R. R. Harbert

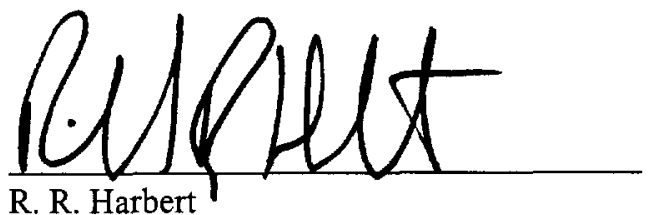

Vice President and General Manager

Environmental Restoration Division

Westinghouse Savannah River Company

Gq-operator for the U.S. Dept of Energy
D. V. Andertor

Environmental Restoration Division

U.S. Department of Energy

Savannah River Field Office

Owner and Co-operator 


\section{EXECUTIVE SUMMARY}

This Statement of Basis/Proposed Plan (SB/PP) is being issued by the U. S. Department of Energy (DOE), which is the lead agency for remedial activities at the Savannah River Site (SRS), with concurrence by the U. S. Environmental Protection Agency (EPA) - Region IV and the South Carolina Department Of Health and Environmental Control (SCDHEC).

The purpose of this plan is to describe the preferred alternative for addressing the Motor Shops Seepage Basin (716-A) (MSSB) located at SRS, in Aiken County, South Carolina and to provide an opportunity for public input into the remedial action selection process. R.61-79.124 of the South Carolina Hazardous Waste Management Regulations (SCHWMR) and Section 117(a) of the Comprehensive Environmental Response, Compensation and Liability Act (CERCLA) require advertisement of the draft Resource Conservation \& Recovery Act (RCRA) permit modification and notice of proposed remedial actions (i.e., the SB/PP).

The selected remedy for the MSSB is No Action. Investigation of this operable unit was performed to determine if hazardous substances at the unit pose an unacceptable risk to human health and the environment. The Baseline Risk Assessment (BRA) indicated that there were no final contaminants of concern for this operable unit. Therefore, it appears that either there were no significant discharges of hazardous materials to the seepage basin or natural remediation processes (e.g., bioremediation) have reduced the levels of hazardous materials to the extent that they no longer pose risk to human health or the environment.

The BRA considered both the future residential and future industrial use scenarios. Benzo[a]pyrene (BAP) was the only preliminary constituent of concern (human health) detected in the soil at MSSB. There were no ecological preliminary constituents of concern. BAP was detected only once and only in the top foot of soil at levels which gave risk values greater than $1 \times 10^{-6}$ (but less than $1 \times 10^{-4}$ ) for the future adult/child resident. Further uncertainty analysis indicated that benzo[a]pyrene should not be considered a constituent of concern for the MSSB due to: 1) low frequency of detection, 2) unit history that strongly suggests it came from an adjacent source, and 3) conservative methodology was utilized in the risk assessment. No ecological or contaminant migration constituents of concern or contaminant migration constituents of concern were identified at this unit. Therefore, No Action is the appropriate remedy.

There were no soil Applicable or Relevant and Appropriate Requirements (ARARs) identified. The Toxic Substances Control Act (TSCA) is considered a To-Be-Considered (TBC) standard for the cleanup of Polychlorinated Biphenyls (PCBs) in soil: For unrestricted land use, the TSCA limits the level of PCBs to $1 \mathrm{mg} / \mathrm{kg}$ in the soil. The levels found in the soil are well below the EPA established cleanup level.

Because there were no soil constituents of concern identified, the No Action alternative was the only remedial alternative considered. No Action will protect human health and the environment and is the appropriate remedy for the MSSB.

The selected remedy is protective of human health and the environment and complies with Federal and State requirements that are legally applicable or relevant and appropriate to the remedial action.

Community involvement in the remedial alternative selection process for the MSSB is strongly encouraged. Section II includes SRS and SCDHEC contact information to request a public meeting, to obtain additional information about this SB/PP, or to submit comments. All submitted comments will be reviewed and considered prior to final selection of an alternative. A Responsiveness Summary will be prepared to address significant issues raised during the public comment period and it will be made available with the final RCRA permit and the Record of Decision (ROD). The final RCRA permit and the ROD document the final decision for the unit. 


\section{TABLE OF CONTENTS}

EXECUTTVE SUMMARY iii

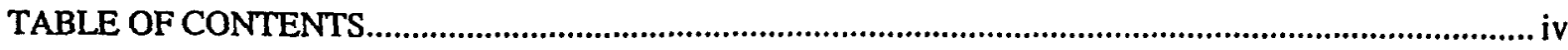

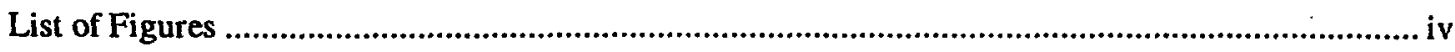

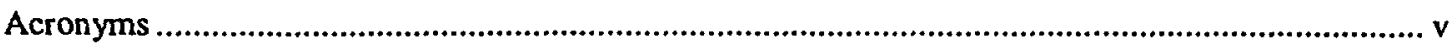

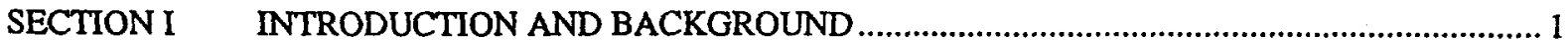

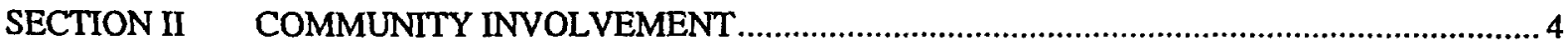

SECTION III SCOPE AND ROLE OF OPERABLE UNIT OR RESPONSE ACTION

SECTION IV MEDIA SPECIFIC OPERABLE UNIT - MSSB ......................................................... 7

Section IV. A. Unit Description, History, and Media to be Addressed ............................................ 7

Unit Description and Location ................................................................................................ 7

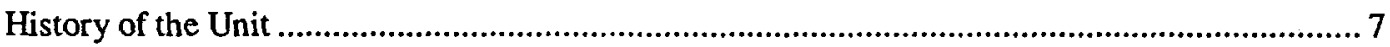

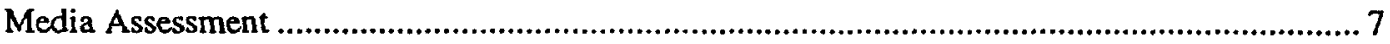

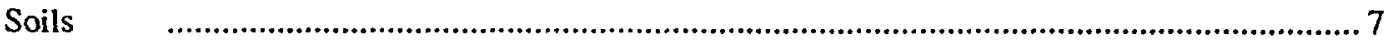

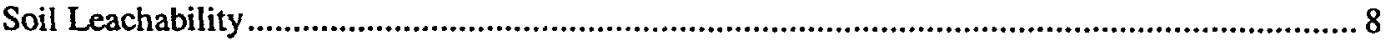

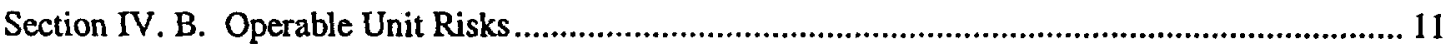

Summary of Human Health Risk Assessment ...................................................................... 11

Summary of Ecological Risk Assessment ....................................................................... 12

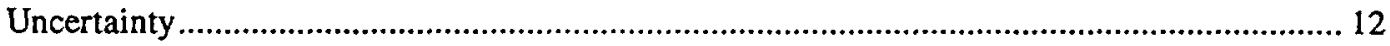

Site-Specific Considerations...................................................................................................... 13

Remedial Action Objectives .................................................................................................. 13

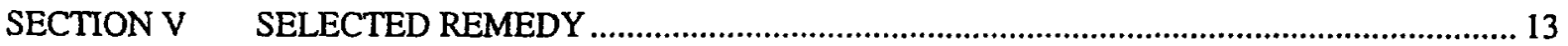

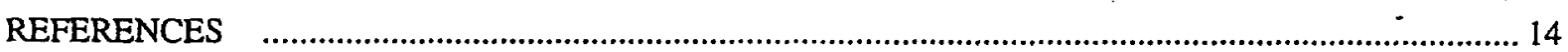

GLOSSARY

\section{List of Figures}

Figure 1. Location of MSSB at the Savannah River Site

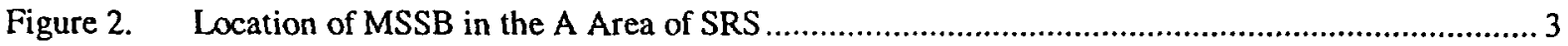

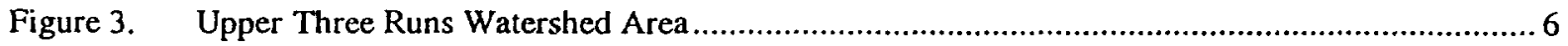

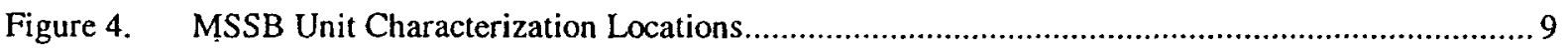

Figure 5. Conceptual Site Model for the Motor Shops Seepage Basin ................................................... 10 


\section{Acronyms}

ARAR Applicable, or Relevant and Appropriate Requirements

BAP

Benzo[a]pyrene

BRA

Baseline Risk Assessment

CERCLA

Comprehensive Environmental Response, Compensation, and Liability Act, 1980

CMCOPC

Contaminant Migration Constituents Of Potential Concern

DOE

U. S. Department Of Energy

ELCR

Excess Lifetime Cancer Risk

EPA

U. S. Environmental Protection Agency

ERA

Ecological Risk Assessment

FFA

Federal Facility Agreement

HI

Hazard Index

HQ

Hazard Quotient

MSSB

Motor Shops Seepage Basin (716-A)

PAH

Polynuclear Aromatic Hydrocarbon

PCB

Polychlorinated Biphenyl

RCRA

Resource Conservation and Recovery Act, 1976

RfD

Reference Dose

RME

Reasonable Maximum Exposure

ROD

Record of Decision

SB/PP

Statement of Basis/Proposed Plan

SCDHEC

South Carolina Department of Health and Environmental Control

SRS

Savannah River Site

SCHWMR

South Carolina Hazardous Waste Management Regulations

SWMU

Solid Waste Management Unit

TBC

To Be Considered

USC

Unit Specific Constituents

WSRC

Westinghouse Savannah River Company 
This page intentionally left blank. 


\section{SECTION I INTRODUCTION AND BACKGROUND}

This Statement of Basis/Proposed Plan (SB/PP) is being issued by DOE, which is the lead agency for SRS remedial activities, with concurrence by EPA and SCDHEC. The purpose of the plan is to describe the preferred alternative for addressing Motor Shops Seepage Basin (MSSB) located in Aiken County, South Carolina and to solicit public comment on the preferred alternative.

SRS manages certain waste materials, which are regulated under RCRA, a comprehensive law, requiring responsible management of hazardous waste. RCRA 3004(u) requires that releases from solid waste management units (SWMU) be investigated and remediated as necessary. MSSB is a SWMU regulated under RCRA 3004(u).

On December 21, 1989, SRS was included on the National Priorities List. This inclusion created a need to integrate the established RCRA Facility Investigation Program with CERCLA requirements to provide for a focused environmental program. In accordance with Section 120 of CERCLA, DOE has negotiated a Federal Facility Agreement (WSRC 1996a) with EPA and SCDHEC to coordinate remedial activities at SRS into one comprehensive strategy which fulfills these dual regulatory requirements.

Both RCRA and CERCLA require that the public be given the opportunity to review and comment on the draft permit modification and proposed remedial alternative. Public participation requirements are listed in SCHWMR R.61-79.124 and Sections 113 and 117 of CERCLA. These requirements include establishment of an Administrative Record File that documents the selection of remedial alternatives and allows for review and comment by the public regarding those alternatives (see Section II). The Administrative Record File must be established "at or near the facility at issue." The SRS Public Involvement Plan (DOE, 1994) is designed to facilitate public involvement in the decision-making process for permitting, closure, and the selection of remedial alternatives. SCHWMR R.61-79.124 and Section 117(a) of CERCLA require advertisement of the draft permit modification and proposed remedial action and provide the public an opportunity to participate in the selection of a remedial action.

SRS occupies approximately 800 square kilometers ( 310 square miles) of land adjacent to the Savannah River, principally in Aiken and Barnwell counties of South Carolina (see Figure 1). SRS is a secured U.S. Government facility with no permanent residents. SRS is located approximately 40 kilometers ( 25 miles) southeast of Augusta, Georgia and 32 kilometers $(20$ miles) south of Aiken, South Carolina.

The MSSB is located in A Area south of the railroad tracks near the automotive shop (Building 716-A) (see Figure 2) in Aiken County. The elevation varies between $104-107 \mathrm{~m}$ (340-350 ft) above mean sea level and slopes gently to the southwest. A small drainage feature runs through the area approximately $91 \mathrm{~m}(300 \mathrm{ft})$ to the east of the MSSB. The headwater is a former National Pollutant Discharge Elimination System-permitted outfall (A-011). This drainage feature turns southwest and discharges into a tributary of Tims Branch. Tims Branch discharges into the Upper Three Runs Creek located $5.6 \mathrm{~km}(3.5 \mathrm{mi})$ to the southeast. There is no surface water connection between the MSSB and the drainage feature. Groundwater is approximately $43 \mathrm{~m}$ (140 ft) below land surface in the A Area and does not outcrop in the vicinity of the MSSB.

The FFA lists MSSB as a RCRA/CERCLA unit, requiring further evaluation using an investigation/assessment process that integrates and combines the RCRA Facility Investigation process with the CERCLA Remedial Investigation to determine the actual or potential impact to human health and the environment.

This SB/PP is a summary of the Administrative Record File leading to selection of the preferred alternative. The plan presents the preferred alternative and the rationale for selecting that alternative. Community involvement in consideration of this evaluation of alternatives for MSSB is strongly encouraged. 


\section{Figure 1. Location of MSSB at the Savannah River Site}

Page 2 of 16

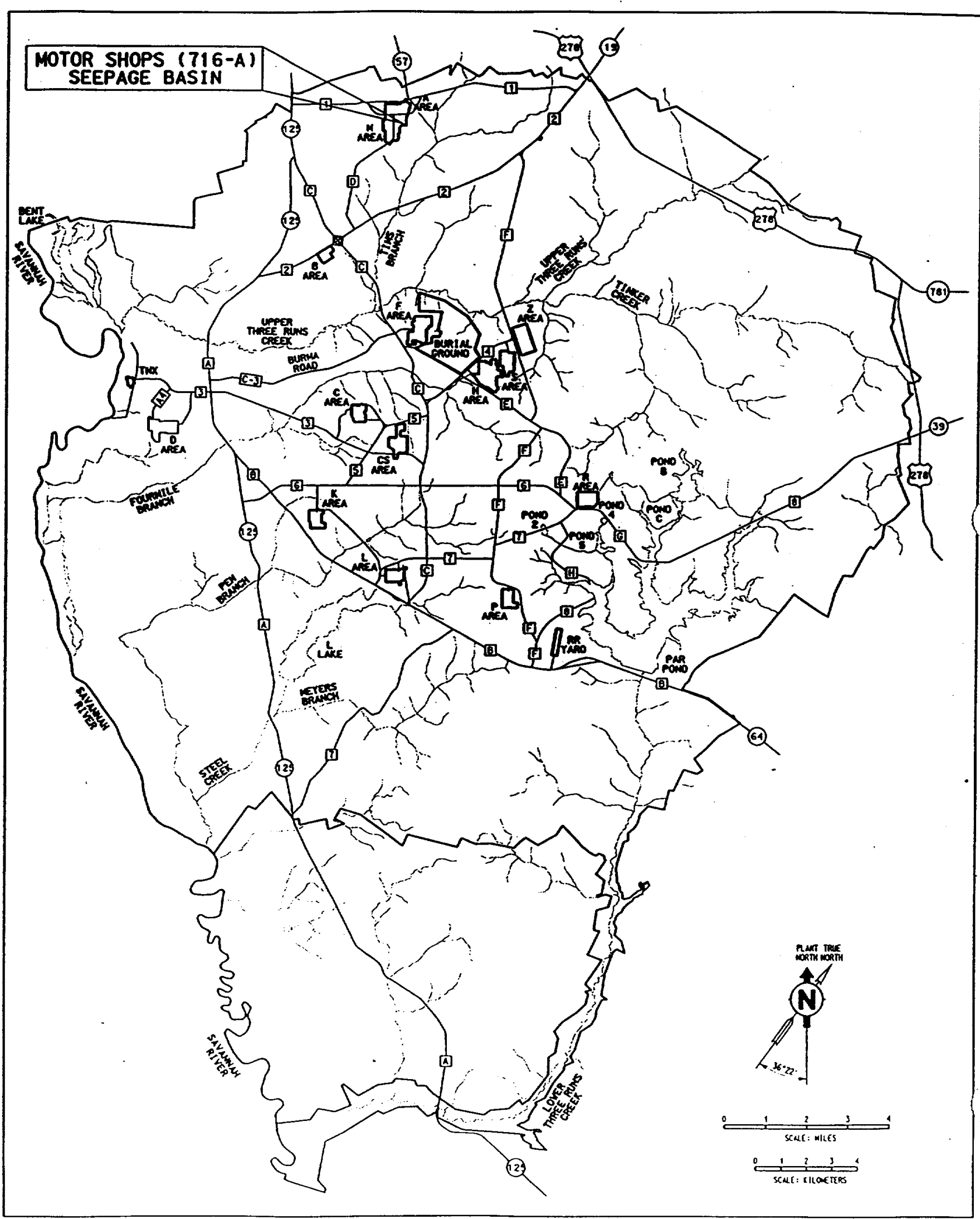


Statement of Basis/Proposed Plan for the Motor Shops Seepage Basin (716-A) (U)

Figure 2. Location of MSSB in the A Area of SRS

Page 3 of 16

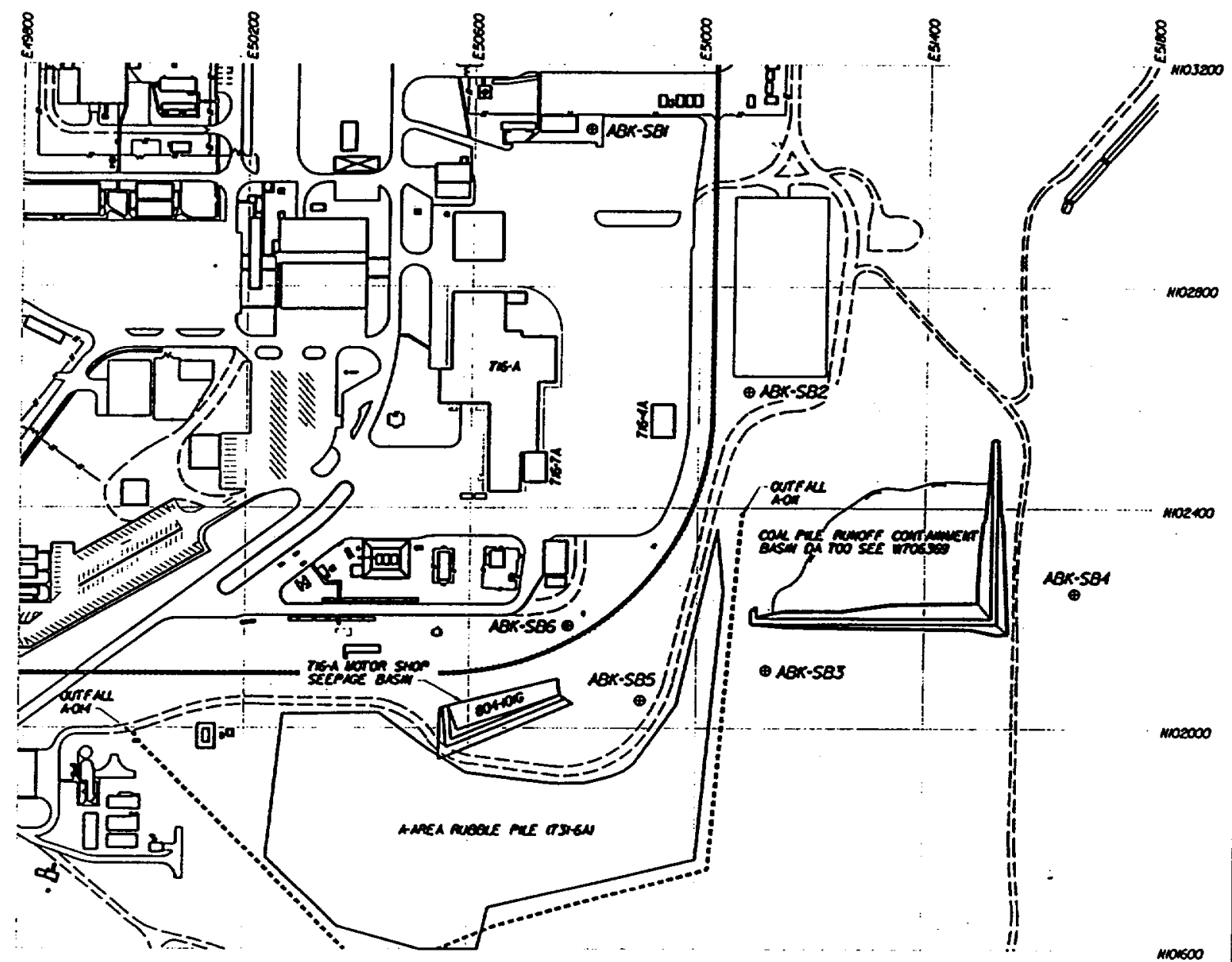

\section{LEGEND}

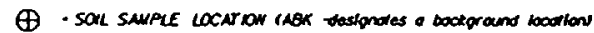

-.... - Orolnoge footure

- Roliros

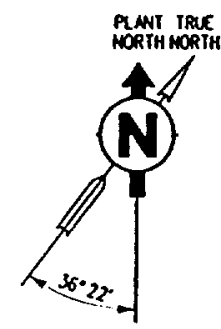


SCHWMR R.61-79.124 requires that a brief description and response to all significant comments be made available to the public as part of the RCRA Administrative Record. All submitted comments will be reviewed and considered. Following the public comment period, a Responsiveness Summary will be prepared to address significant issues raised during the comment period. The Responsiveness Summary will be made available with the final RCRA permit and the ROD. In order to gain a better understanding of RCRA and CERCLA activities as they pertain to MSSB, the public is encouraged to review the Administrative Record File for this unit. Refer to Section II of this document for information regarding availability and access.

RCRA also provides opportunities for the public to comment on draft permit modifications. The preferred alternative proposed in this Statement of Basis/Proposed Plan is also being proposed as a draft permit modification under RCRA. Therefore, any comments received on this Statement of Basis/Proposed Plan will also be applicable to the draft RCRA permit modification, proposing the same remedy for this waste unit.

The final selection of the remedial alternative under RCRA will be in the form of a final permit modification decision, which is made by SCDHEC. The final selection of the remedial alternative, that will satisfy the FFA requirements, will be made by DOE, in consultation with EPA and SCDHEC, only after the public comment period has ended and all comments submitted have been reviewed and considered. It is important to note that the final action may be different from the preferred alternative discussed in this plan, depending on new information or public comments. The alternative chosen will be protective of human health and the environment and will comply with all Federal and state environmental laws.

\section{SECTION II COMMUNITY INVOLVEMENT}

This document summarizes information that is provided in greater detail in the FFA
Administrative Record File, which is available for review by the public at the following locations:

\author{
U. S. Department of Energy \\ Public Reading Room \\ Gregg-Graniteville Library \\ University of South Carolina-Aiken \\ 171 University Parkway \\ Aiken, South Carolina 29801 \\ (803) 641-3465
}

Thomas Cooper Library

Government Bocuments Department

University of South Carolina

Columbia, South Carolina 29208

(803) $777-4866$

Similar information is available through the repositories listed below:

Reese Library

Augusta State University

2500 Walton Way

Augusta, Georgia 30910

(706) $737-1744$

Asa H. Gordon Library

Savannah State University

Thompkins Road

Savannah, Georgia 31404

(912) 356-2183

The RCRA Administrative Record file for SCDHEC is available for review by the public at the following locations:

The South Carolina Department of .Health and Environmental Control

Bureau of Solid and Hazardous Waste Management

8901 Farrow Road

Columbia, South Carolina 29203

(803)896-4000

Lower Savannah District

Environmental Quality Control Office

215 Beaufort St., N. E.

Aiken, South Carolina 29802

(803)641-7670 
The public will be notified of a public comment period through mailing of the SRS Environmental Bulletin, a newsletter sent to approximately 3500 citizens in South Carolina and Georgia, and through the Aiken Standard, the Allendale Citizen Leader, the Barnwell People Sentinel, The State, and the Augusta Chronicle newspapers. The public comment period will also be announced on local radio stations.

DOE will provide an opportunity for a public meeting during the public comment period if significant interest is expressed. The public will be notified of the date, time, and location. At the meeting, the proposed action will be discussed and questions about the action will be answered. To request a public hearing during the public comment period, to obtain more information concerning this Statement of Basis/Proposed Plan, or to submit written comments contact one of the following:

Mary A. Flora

Public Involvement

Westinghouse Savannah River Co.

Building 703-A

Savannah River Site

Aiken, SC 29808

1-800-249-8155

mary.flora@srs.gov

The South Carolina Department of Health and Environmental Control

Attn.: J. T. Litton, Director

Division of Hazardous and Infectious Waste Management

Bureau of Land and Waste Management

2600 Bull Street

Columbia, South Carolina 29201

(803) 896-4000
Following the public comment period, a ROD will be signed and a final decision for the RCRA permit will be issued. The ROD and RCRA permit will detail the remedial alternative chosen for the site and will include responses to oral and written comments received during the public comment period in the Responsiveness Summary. SCDHEC will issue a permit modification incorporating this remedy into the SRS RCRA permit.

\section{SECTION III SCOPE AND ROLE OF OPERABLE UNIT OR RESPONSE ACTION WITHIN THE SITE STRATEGY}

The overall strategy for addressing the MSSB was to: (1) characterize the waste unit delineating the nature and extent of contamination and identifying the media of concern (perform the RCRA Facility Investigation/Remedial Investigation); (2) perform a baseline risk assessment to evaluate media of concern, constituents of concern, exposure pathways, and characterize potential risks; and (3) evaluate and perform a final action to remediate, as needed, the identified media of concern.

The MSSB is an operable unit included in the Upper Three Runs watershed (See Figure 3). The ground surface in the vicinity of the unit slopes gently to the southeast in the direction of Tims Branch. Tims Branch, the closest natural surface water drainage, is located approximately $1220 \mathrm{~m}$ $(4000 \mathrm{ft})$ from the unit. There is no surface water connection between the MSSB and Tims Branch or any drainage feature in the area. Groundwater does not outcrop in the vicinity of the MSSB.

No action, the preferred remedy for this operable unit, is a final action. 
Figure 3. Upper Three Runs Watershed Area

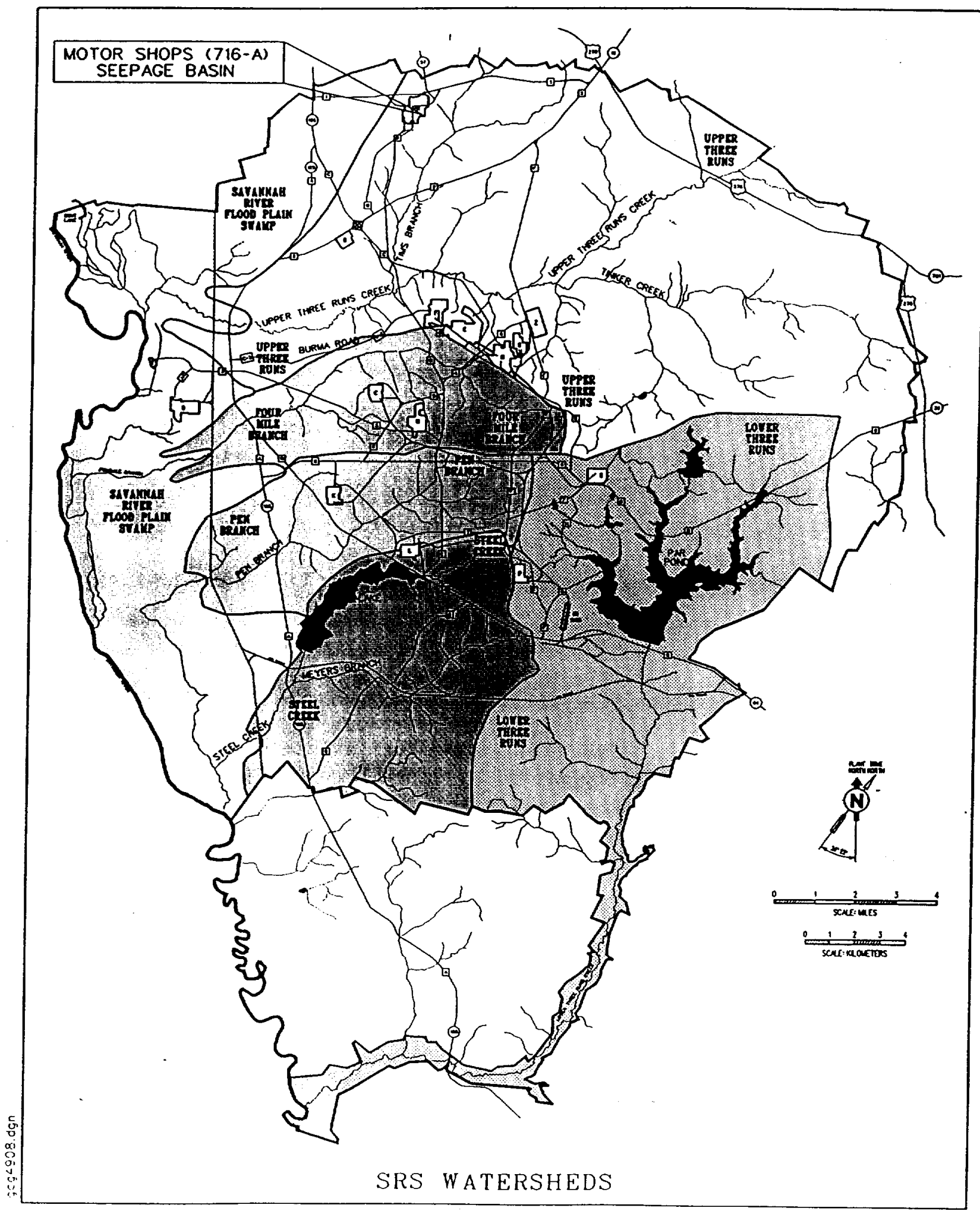




\section{SECTION IV MEDIA SPECIFIC OPERABLE UNIT - MSSB}

\section{Section IV. A. Unit Description, History, and Media to be Addressed}

\section{Unit Description and Location}

The MSSB is located in A Area south of the railroad tracks near the automotive shop (Building 716-A) (see Figure 2) in Aiken County. The elevation varies between $104-107 \mathrm{~m} \mathrm{(340-350 \textrm {ft } )}$ above mean sea level and slopes gently to the southwest. A small drainage feature runs through

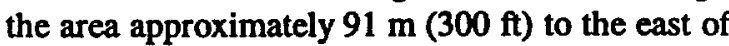
the MSSB. The headwater is a former National Pollutant Discharge Elimination System-permitted outfall (A-011). This drainage feature turns southwest and discharges into a tributary of Tims Branch. Tims Branch discharges into the Upper Three Runs Creek located $5.6 \mathrm{~km}$ ( $3.5 \mathrm{mi})$ to the southeast. Groundwater is approximately $46 \mathrm{~m}$ (150 ft) below land surface in the A Area and does not outcrop in the vicinity of the MSSB.

\section{History of the Unit}

The MSSB was constructed and placed in service in 1977 to receive liquid waste from the 716-A Motor Shops oil/water separator. The MSSB was designed and constructed as an unlined seepage basin. The basin measures $63.1 \mathrm{~m}(207.0 \mathrm{ft})$ long, $10.7 \mathrm{~m}(35.1 \mathrm{ft})$ wide, and $2.0 \mathrm{~m}(6.6 \mathrm{ft})$ deep (Huber et al. 1987). It is surrounded by a berm 2.0 $\mathrm{m}(6.6 \mathrm{ft}) \mathrm{high}$. The wastewater flowed into the basin from the northwest through two influent pipes from the Motor Shop (Building 716-A) and seeped naturally into the soil beneath the basin. The basin has not been closed or capped, but all discharges to the basin were terminated in 1983 when the influent lines from the Motor Shops were capped (Huber et al. 1987). Effluent discharges from the Motor Shops included wastewater with trace amounts of engine oil, grease, kerosene, ethylene glycol, and soapy water. A ramp was built into the eastern end of the basin in 1988 (WSRC 1990) to facilitate soil sampling. At present, the basin collects rainwater during periods of heavy precipitation.

\section{Media Assessment}

Hand-augered soil borings were made at locations ABK-SB1 through ABK-SB6 (Figure 2) during the Phase $I$ investigation to establish background conditions for unit soils. These locations are topographically and hydraulically upgradient from the MSSB. The samples were collected from Udorthent soils at sample depths corresponding to the depth of samples collected from the basin. Two soil samples were collected at each location at depth intervals of 0-0.3 m (0-1 ft) and 0.3-1.2 m (1-4 ft) below land surface. Background soil sample locations were carefully selected and are spread out over a large area due to the presence of existing buildings, roads, and other facilities. The sampling locations were in areas considered to be unaffected by potential contamination from the MSSB.

Background values are calculated by averaging the constituent concentrations detected in all six surface soil samples. If there was a non-detection for a given analyte, one-half of the maximum detection limit was used. The twice average concentration levels are then compared to detections in unit surface soil samples as a screening level.

Background values for subsurface soils are calculated similarly to surface soils, except that all 12 samples are used (i.e., six samples from 0-0.3 $\mathrm{m}$ [0-1 ft] and six samples from 0.3-1.2 m [1-4 ft] below land surface). The twice average concentration levels are then used for comparisons to unit subsurface soil sample detections.

Deep soils, process sewer line soils, and groundwater were to be sampled during the Phase II investigation, however, based on the Phase I (worst case) results, Phase II was not required.

Soils

Within the basin, hand-augered soil borings were advanced at six locations, AOB-SB1 through AOB-SB6 (Figure 4), during the Phase I investigation. Two soil samples were collected at each location at depth intervals of $0-0.3 \mathrm{~m}(0-1 \mathrm{ft})$ and $0.3-1.2 \mathrm{~m}(1-4 \mathrm{ft})$ bls. The only USC identified 
for the MSSB is BAP, which was detected in one of 12 soil samples at a concentration exceeding both its risk-based concentration and twice average background level.

Polynuclear Aromatic Hydrocarbons (PAHs), such as BAP, can be derived from oil, coal, charcoal, or other similar substances and may be of anthropogenic or natural origin. They are not very mobile and tend to readily adsorb to soils. Based on the disposal history of the MSSB, this occurrence of BAP may be unit related. However, the compound's limited frequency of detection in MSSB soils, together with the unit's proximity to a railroad known to carry coal, suggests another possible source for this contamination.

The conceptual site model (see Figure 5) identifies soil, groundwater, air, and biota as possible exposure pathways for contamination from the MSSB. Groundwater was not sampled during the Phase I investigation. Groundwater sampling was to be performed during Phase II; however, since only one USC was detected in Phase I unit soil samples, the Phase II investigation was deemed unwarranted. The decision rules presented in the work plan for the MSSB (1996b) supported terminating the investigation if no subsurface contamination from the basin was found during Phase I. Area groundwater is under evaluation as part of the overall groundwater remediation approach as presented in the RCRA permit application Corrective Action Plan for the A-014 outfall area (Volume III, M-Area HWMF, WSRC-IM-91-53). Biota and air also were not sampled during the Phase I investigation. Potential contaminant concentrations in biota and air are derived during the BRA based on constituent levels measured in surface and subsurface soils.

The soils along the process sewer line were also to be characterized during the Phase II investigation if warranted by Phase I results. The Phase I soil results represent the worst case scenario for the MSSB. Based on the low levels of contamination detected and the identification of only one USC, soil sampling along the process sewer line was also deemed unwarranted.

\section{Soil Leachability}

For the purpose of soil leachability analysis, contaminant migration constituents of potential concern (CMCOPCs) are defined as constituents detected in unit soils with a maximum concentration greater than twice their average background level. Two inorganic CMCOPCs (antimony and cadmium) and three organic CMCOPCs (benzo(a)anthracene, benzo(g,h,i)perylene, and phenanthrene) were retained for soil leachability evaluations.

Soil leachability calculations were performed using detailed, unit-specific equations in accordance with EPA soil screening guidance. The equations estimated the concentrations of the CMCOPCs at the base of the vadose zone. Groundwater concentrations were then calculated from these values by applying a groundwater dilution factor. The nature of the input data and the analytical equation assumptions are such that the estimates of groundwater concentrations are conservative.

Based on the results of the equations, none of the organic CMCOPCs are predicted to leach into groundwater and none of the inorganic CMCOPCs are estimated to reach maximum concentration within 1000 years. Therefore, none of the CMCOPCs calculated for the MSSB are likely to pose a future human health risk due to ingestion of groundwater. 


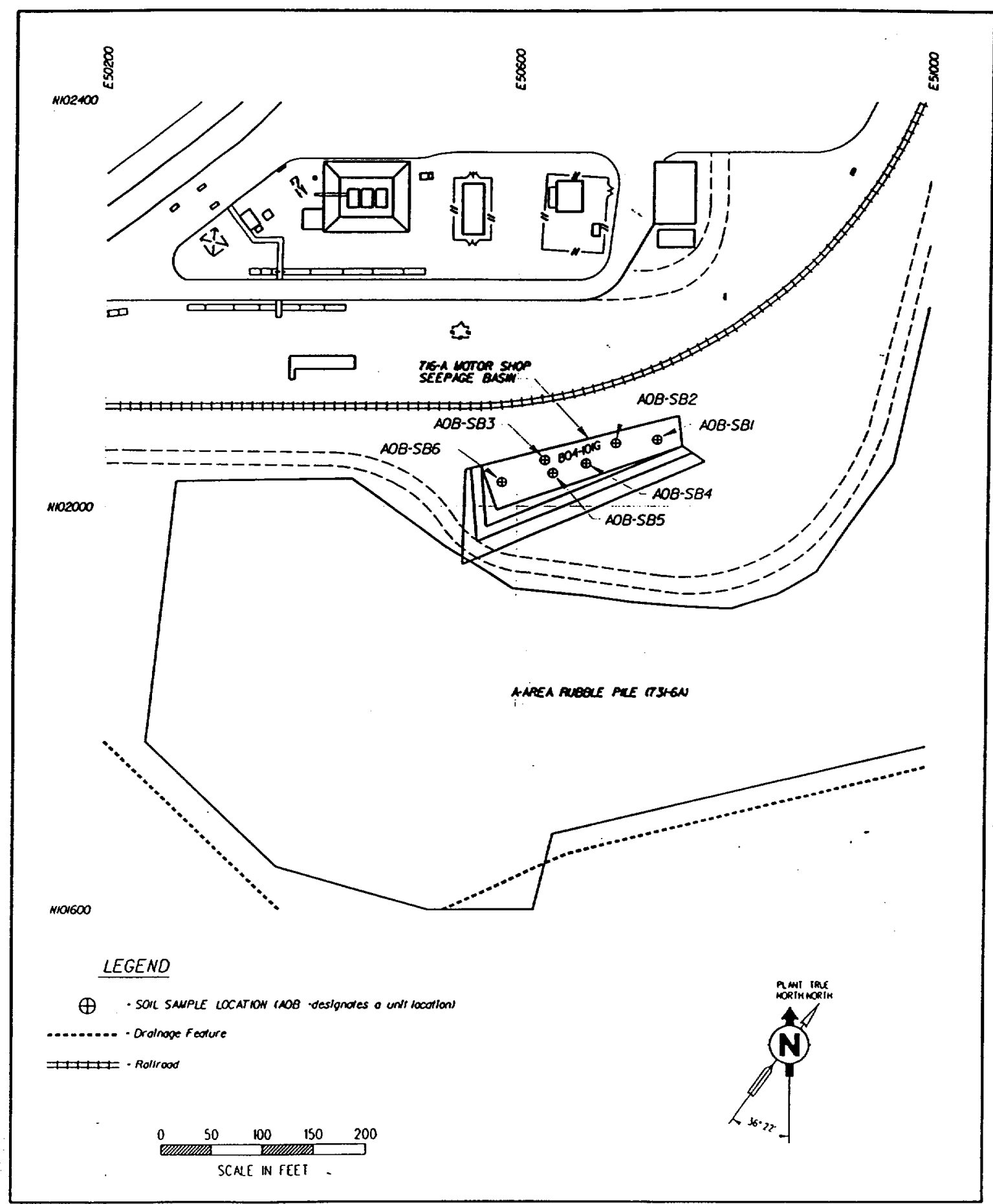




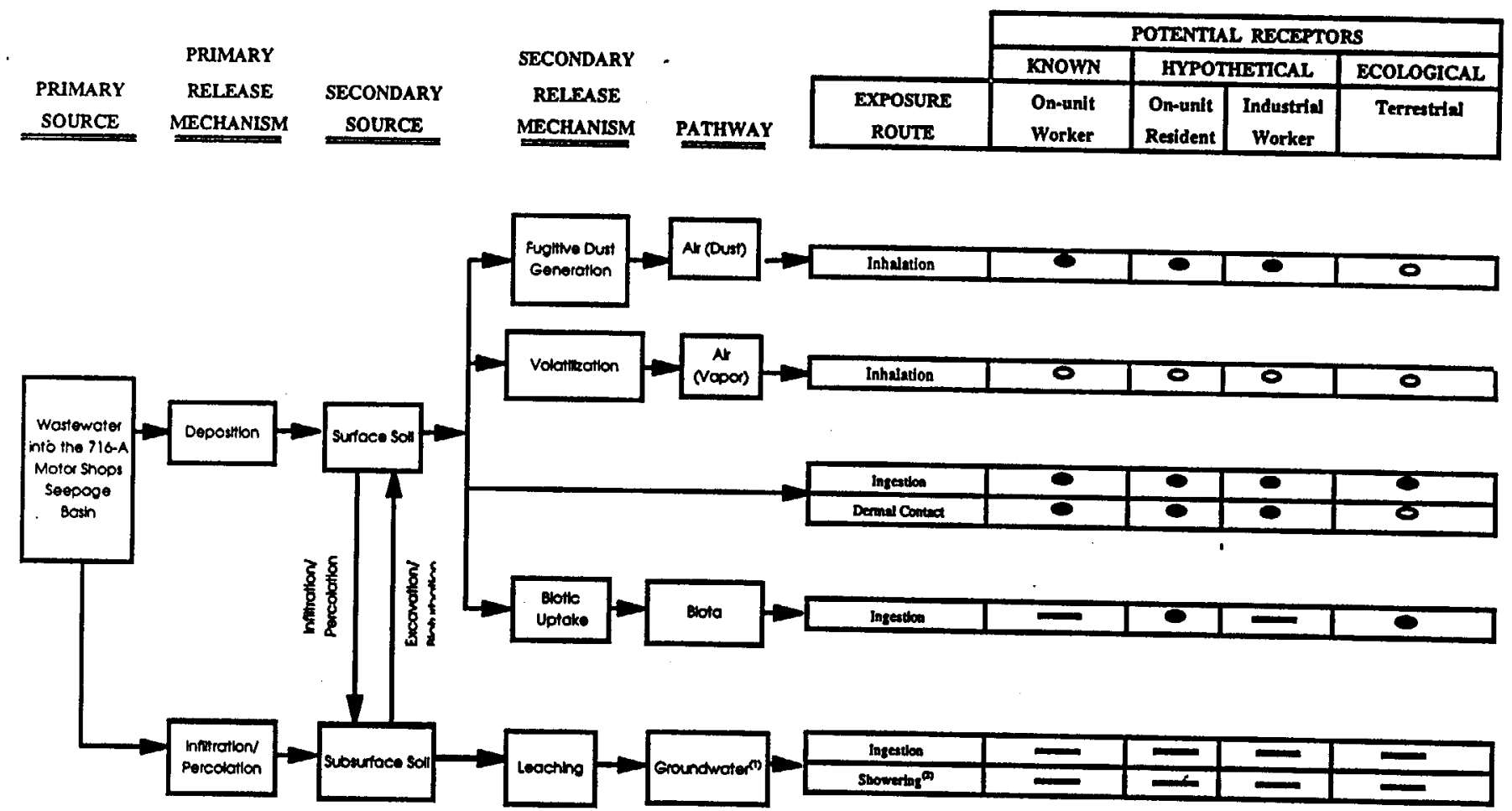

(1) Characterization of groundwater was not required based on Phase I results. (2) Includes inhalation and demal contact.

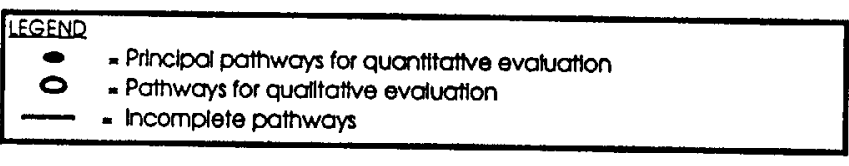




\section{Section IV. B. Operable Unit Risks}

As a component of the remedial investigation process, a baseline risk assessment was prepared for the MSSB. The baseline risk assessment consists of human health and ecological risk assessments.

\section{Summary of Human Health Risk Assessment}

Carcinogenic risks are estimated as the incremental probability of an individual developing cancer over a lifetime as a result of pathway-specific exposure to cancer-causing contaminants. The risk to an individual resulting from exposure to non-radioactive chemical carcinogens is expressed as the increased probability of cancer occurring over the course of a 70 year lifetime. Cancer risks are related to the EPA target risk range of one in ten thousand ( $1 \mathrm{x}$ $\left.10^{-4}\right)$ to one in one million $\left(1 \times 10^{-6}\right)$ for incremental cancer risk at National Priorities List sites. Risk levels in the $1 \times 10^{-4}$ to $1 \times 10^{-6}$ range require a risk management decision where specific actions to reduce risk may be considered while cancer risk levels below $1 \times 10^{-6}$ are considered to be insignificant.

Non-carcinogenic effects are also evaluated to identify a level at which there may be concern for potential non-carcinogenic health effects. The hazard quotient, which is the ratio of the exposure dose to the reference dose (RfD), is calculated for each contaminant. Hazard quotients are summed for each exposure pathway to determine the specific hazard index (HI) for each exposure scenario. If the $\mathrm{HI}$ exceeds unity (1.0), the potential exists that adverse health effects might occur.

\section{Current Land Use Results}

Under the current land use scenario, carcinogenic risks and noncarcinogenic hazards are characterized for exposure of an on-unit worker to soil. Known on-unit workers are expected to be exposed to surface soils $(0-0.3 \mathrm{~m}[0-1 \mathrm{ft}])$.

\section{Noncarcinogenic Hazard}

There are no noncarcinogenic $\mathrm{HI}$ values for the known on-unit worker exposure pathways because reference dose values for noncancer effects are not available for benzo(a)pyrene, the only unit preliminary constituent of concern.

\section{Carcinogenic Risk}

All of the estimated total cancer risks are less than $1 \times 10^{-6}$, indicating that, under current conditions, carcinogenic risk is insignificant at the unit. For the $0-0.3 \mathrm{~m}(0-1 \mathrm{ft})$ soil interval, the total cancer risk for the known on-unit worker is $1 \times 10^{-8}$.

\section{Future Land Use Results}

The future hypothetical on-unit workers are assumed to be exposed to surface soils $(0-0.3 \mathrm{~m}$ [0-

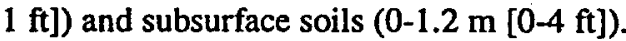

\section{Hypothetical On-Unit Industrial Worker}

Under the future land use scenario, carcinogenic risks and noncarcinogenic hazards are calculated for exposure of the hypothetical on-unit resident (adult and child) to surface and redistributed subsurface soils, and homegrown produce. For the hypothetical on-unit worker, exposures are to surface soil and redistributed subsurface soil (but not produce).

\section{Noncarcinogenic Hazard}

There are no noncarcinogenic HIs for the hypothetical on-unit worker exposure pathways because reference dose values for noncancer effects are not available for benzo(a)pyrene, the only unit preliminary constituent of concern.

\section{Carcinogenic Risk}

For the 0-0.3 m (0-1 ft) and the 0-1.2 m (0-4 ft) soil intervals, the total cancer risk for the hypothetical on-unit industrial worker is $3 \times 10^{-6}$. The risk is from benzo(a)pyrene in the dermal contact pathway. 


\section{Hypothetical On-Unit Resident}

The future hypothetical on-unit residents are assumed to be exposed to surface soils (0-0.3 m [0$1 \mathrm{ft}])$ and subsurface soils $(0-1.2 \mathrm{~m}$ [0-4 ft]). Hypothetical residents are also assumed to, be exposed to homegrown produce.

\section{Noncarcinogenic Hazard}

There are no noncarcinogenic HIs for the hypothetical on-unit resident exposure pathways because reference dose values for noncancer effects are not available for benzo(a)pyrene, the only unit preliminary constituent of concern.

\section{Carcinogenic Risk}

For the $0-0.3 \mathrm{~m}(0-1 \mathrm{ft})$ soil interval, the total cancer risk for the hypothetical on-unit resident is $1 \times 10^{-5}$. This is below $1 \times 10^{-4}$, but exceeds the initial level of concern for cancer risk $\left(1 \times 10^{-6}\right)$. Pathways with cancer risks of greater than $1 \times 10^{-6}$ include soil ingestion (Excess Lifetime Cancer Risk [ELCR] $\left.=3 \times 10^{-6}\right)$, dermal contact $\left(5 \times 10^{-6}\right)$, and ingestion of produce $\left(2 \times 10^{-6}\right)$ grown in the soil. Benzo(a)pyrene, which is a secondary constituent of concern, is the only constituent of concern identified for the $0-0.3 \mathrm{~m}(0-1 \mathrm{ft})$ soil interval.

For the $0-1.2 \mathrm{~m}(0-4 \mathrm{ft})$ soil interval, the total cancer risk for the hypothetical on-unit resident is $1 \times 10^{-5}$. This is below $1 \times 10^{-4}$, but exceeds the initial level of concern for cancer risk $\left(1 \times 10^{-6}\right)$. Pathways with cancer risks of greater than $1 \times 10^{-6}$ include soil ingestion (ELCR $=3 \times 10^{-6}$ ), dermal contact $\left(5 \times 10^{-6}\right)$, and ingestion of produce $(2 \times$ $10^{-6}$ ) grown in the soil. Benzo(a)pyrene, which is a secondary constituent of concern, is the only preliminary constituent of concern identified for the $0-1.2 \mathrm{~m}(0-4 \mathrm{ft})$ soil interval.

\section{Summary of Ecological Risk Assessment}

The purpose of the ecological risk assessment (ERA) component of the BRA is to evaluate the likelihood that adverse ecological effects may occur or are occurring as a result of exposure to unit-related constituents based on a weight-of- evidence approach. An ecological risk does not exist unless a given constituent has the ability to cause one or more adverse effects and it either cooccurs with, or is contacted by, an ecological receptor for a sufficient length of time or at a sufficient intensity to elicit the identified adverse effect(s).

The assessment endpoint at the MSSB is the maintenance of the terrestrial ecosystem, with no loss of species or community alteration due to antimony or cadmium toxicity, the only ecological constituents of potential concern. The testable hypothesis is that the reasonable maximum exposure (RME) concentrations of antimony and cadmium present in surface and subsurface soils are not toxic to terrestrial animals at the unit. To verify or recant the testable hypothesis, a receptor species, the oldfield mouse, is selected to represent the assessment endpoint. Since it is unlikely that antimony bioaccumulates or cadmium biomagnifies in the food chain, direct measurement of antimony and cadmium concentrations in soil media, to be modeled to concentrations in the oldfield mouse, is selected as the appropriate measurement endpoint.

The ERA confirms that the RME concentrations of antimony and cadmium present in soils at the unit are not toxic to terrestrial animals at the unit. No ecological constituent of concern are identified at the MSSB waste unit. No hazard quotients (HQs) at the MSSB are greater than 1. The constituents detected in surface and subsurface soils at the unit do not pose unacceptable risk, do not threaten the assessment endpoint for the unit, and do not impact the policy goal applicable to the unit.

\section{Uncertainty}

Benzo(a)pyrene is the only human health preliminary constituent of concern detected in surface soils (0-0.3 m [0-1 ft] interval). It exceeds human health risk-based criteria (highest risk $=1$ $\times 10^{-5}$ for the hypothetical adulu/child receptor); the dermal pathway is the most significant risk contributor, $5 \times 10^{-6}$. Benzo(a)pyrene was not detected in the subsurface soils greater than $0.3 \mathrm{~m}$ ( $1 \mathrm{ft}$ ). Although benzo (a)pyrene exceeds human 
health risk-based criteria, it is eliminated from further consideration as a constituent of concern for the following reasons:

- The use of $1 \mathrm{mg} / \mathrm{cm}^{2}$ as the soil-to-skin adherence factor is high, which causes the risk to be high and very conservative in nature.

- When comparing central tendency exposure risk estimates to RME estimates, the combined central tendency exposure estimates are an order of magnitude lower than the RME estimates for both the industrial worker and the adult/child receptors. Risks are probably significantly overestimated by using the $\mathrm{RME}$ value and a high soil adherence factor. The central tendency exposure risk estimates are, by definition, representative of more likely exposures than are the RME estimates.

- Benzo(a)pyrene was detected in one out of six surface (0-1 ft) soil samples and in one out of 12 subsurface soil samples (which includes the $0-0.3 \mathrm{~m}[0-1 \mathrm{ft}]$ interval). Therefore, the frequency of detection is very low.

- Benzo(a)pyrene was detected in two of six background samples for the surface soils. Organics are not screened out based on background comparisons as part of the preliminary constituent of concern selection process for the risk assessment.

Since benzo(a)pyrene is eliminated from further consideration as a constituent of concern, no human health RGOs are determined for this unit.

\section{Site-Specific Considerations}

Site-specific considerations, based on the conclusions of the BRA and RCRA Facility Investigation/Remedial Investigation, which suggest limited or no potential for significant risk include:

1) No samples were taken from the primary source of contamination (i.e., wastewater) because wastewater is no longer discharged to the seepage basin. The only Unit Specific
Constituent (USC) found in the secondary sources of contamination (i.e., surface soil and subsurface soil) was BAP. BAP is a PAH. PAHs can be derived from oil, coal, charcoal, or other similar substances and may be of anthropogenic or natural origin. They are not very mobile and tend to readily adsorb to soils. Based on the disposal history of the MSSB, this occurrence of benzo(a)pyrene may be unit related. However, the compound's limited frequency of detection in MSSB soils, together with the unit's proximity to a railroad known to carry coal, strongly suggests another possible source for this contamination.

2) While risk calculations for BAP indicated risk levels for hypothetical future adult/child residents which exceeded $1 \times 10^{-6}$, uncertainty analysis eliminated BAP as a constituent of concern. BAP was the only human health constituent of concern carried through the risk analysis. Therefore, with BAP eliminated, there are no human health risks in excess of $1 \times 10^{-6}$, no HIs in excess of 1.0 , no contaminant migration constituents that will affect groundwater, and no ecological constituents of concern for the MSSB.

\section{Remedial Action Objectives}

There were no COCs identified for this unit, so development of remedial action objectives was unnecessary. Although PCB was found in two samples, the levels found were significantly less than the TSCA cleanup guidance.

\section{SECTION V SELECTED REMEDY}

The selected remedy for MSSB is No Action.

This proposal is consistent with EPA guidance and is an effective use of risk management principles. The Statement of Basis/Proposed Plan provided for involvement with the community through a document review process and a public comment period. Public input will be documented in the Responsiveness Summary of the Record of Decision. 


\section{REFERENCES}

DOE (U. S. Department of Energy), 1994. Public Involvement, A Plan for Savannah River Site. Savannah River Operations Office, Aiken South Carolina.

DOE, 1996. Savannah River Site Future Use Project Report. U. S. Department of Energy Savannah River Operations Office, Aiken, South Carolina, January, 1996.

Huber, L. A., W.F. Johnson, and H. W. Bledsoe, 1987. Environmental Information Document: Waste Oil Basins. DPST-85-701. E.I. du Pont de Nemours and Company, Savannah River Laboratory, Aiken, South Carolina.

WSRC (Westinghouse Savannah River Company), 1990. RCRA Facility Investigation/ Remedial Investigation Plan for the 716-A Motor Shops Seepage Basin. WSRC-RP-90-581. Westinghouse Savannah River Company, Savannah River Site, Aiken, South Carolina.

WSRC (Westinghouse Savannah River Company), 1996a. Savannah River Site Federal Facility Agreement Implementation Plan, Revision 0. WSRC-RP-94-1200. Savannah River Site, Aiken, South Carolina. August 1996.

WSRC, 1996b. RCRA Facility Investigation /Remedial Investigation Work Plan for the 716-A Motor Shops Seepage Basin, Revision 0. WSRC-RP-96-00111. Savannah River Site, Aiken, South Carolina: Westinghouse Savannah River Company.

WSRC, 1997a. RCRA Facility Investigation / Remedial Investigation Report With the Baseline Risk Assessment for the 716-A Motor Shops Seepage Basin (U), WSRC-RP-99-134, Revision 1, Westinghouse Savannah River Company, Aiken, South Carolina (August, 1997).
WSRC, 1997b. Statement of Basis/Proposed Plan for the Motor Shops Seepage Basin (716-A) (U), WSRC-RP-97-839, Revision 0, Westinghouse Savannah River Company, Aiken, South Carolina (December 1997). 


\section{GLOSSARY}

Administrative Record File: A file that is maintained and contains all information used to make a decision on the selection of a response action under the Comprehensive Environmental Response, Compensation \& Liability Act. This file is to be available for public review, and a copy is to be established at or near the Site, usually at one of the information repositories. Also a duplicate file is held in a central location, such as a regional or state office.

ARARs: Applicable, or Relevant and Appropriate Requirements. Refers to the federal and state requirements that a selected remedy will attain. These requirements may vary from site to site.

Baseline Risk Assessment: Analysis of the potential adverse health effects (current or future) caused by hazardous substance release from a site in the absence of any actions to control or mitigate these releases.

Characterization: The compilation of all available data about the waste units to determine the rate and extent of contaminant migration resulting form the waste site, and the concentration of any contaminants that may be present.

\section{Comprehensive Environmental Response,} Compensation and Liability Act (CERCLA), 1980: A Federal law passed in 1980 and modified in 1986 by the Superfund Amendments and Reauthorization Act. The Acts created a special tax that goes into a Trust Fund, commonly known as Superfund, to investigate and clean up abandoned or uncontrolled hazardous waste sites.

Corrective Action: An EPA requirement to conduct remedial procedures under RCRA 3998(h) at a facility when there has been a release of hazardous waste or constituents into the environment. Corrective action may be required beyond the facility boundary and can be required regardless of when the waste was placed at the facility.
Exposure: Contact of an organism with a chemical or physical agent. Exposure is quantified as the amount of the agent available at the exchange boundaries of the organism (e.g., skin, lungs, digestive tract, etc.) and available for absorption.

Federal Facility Agreement (FFA): The legally binding agreement between regulatory agencies (EPA and SCDHEC) and regulated entities (DOE) that sets the standards and schedules for the comprehensive remediation of the SRS.

Media: A pathway through which contaminants are transferred. Five media by which contaminants may be transferred are groundwater, soil, surface water, sediments, and air.

National Priorities List : EPA's formal list of the nation's most serious uncontrolled or abandoned waste sites, identified for possible long-term remedial response, as established by CERCLA.

Operable Unit (OU): A discrete action taken as one part of an overall site cleanup. The term is also used in EPA guidance documents to refer to distinct geographic areas or media-specific units within a site. A number of operable units can be used in the course of a cleanup.

Operation and Maintenance (O\&M): Activities conducted at a site after a response action occurs to ensure that the cleanup and/or systems are functioning properly.

Overall Protection of Human Health and the Environment: The assessment against this criterion describes how the alternative, as a whole, achieves and maintains protection of human health and the environment.

Proposed Plan: A legal document that provides a brief analysis of remedial alternatives under consideration for the site/operable unit and proposes the preferred alternative. It actively solicits public review and comment on all alternatives under consideration. 
Reasonable Maximum Exposure (RME): This is the value that the average concentration will fall below 95 percent of the time.

Record Of Decision (ROD): A legal document that explains to the public which alternative will be used at a site/operable unit. The record of decision is based on information and technical analysis generated during the remedial investigation/ feasibility study and consideration of public comments and community concerns.

Resource Conservation and Recovery Act (RCRA), 1976: A Federal law that established a regulatory system to track hazardous substances from their generation to disposal. The law requires safe and secure procedures to be used in treating, transporting, storing, and disposing of hazardous substances. RCRA is designed to prevent the creation of new, uncontrolled hazardous waste sites.

Responsiveness Summary: A summary of oral and/or written comments received during the proposed plan comment period and includes responses to those comments. The responsiveness summary is a key part of the ROD, highlighting community concerns.

Statement of Basis: A report describing the corrective measures/remedial actions being conducted pursuant to South Carolina Hazardous Waste Management Regulations, as amended.

Superfund: The common name used for CERCLA; also referred to as the Trust Fund. The Superfund program was established to help fund cleanup of hazardous waste sites. It also allows for legal action to force those responsible for the sites to clean them up.

Target Risk Range: EPA guidance for carcinogenic risk due to exposure to a known or suspected carcinogen between one excess cancer in an exposed population of ten thousand $\left(1.0 \times 10^{-4}\right)$ and one excess cancer in an exposed population of one million $\left(1.0 \times 10^{-6}\right)$. Risks within this range require risk management evaluation of remedial action alternatives to determine if risks can be reduced below one excess cancer in million $\left(1.0 \times 10^{-6}\right)$. Risks greater than $1.0 \times 10^{-4}$ indicate that remedial action is generally warranted. 